\title{
The Organisation Network in Reducing Poverty at Kendari City
}

\author{
Joko Tri Brata \\ University of Souteast Sulawesi 109. Piere Tendean Street Kendari - Indonesia.
}

\begin{abstract}
Poverty is a problem for all nations and countries. The general problems of poverty are caused by the lack of coordination between programs and indication of the inter-agency sectoral ego, so sometimes provoke confusion until frictions among the stakeholders in the region. The purpose of this study was to clarify the application of the network model in poverty alleviation in Kendari city.This study uses a qualitative method that is expalanative in order to understand the concept of organization network in reducting poverty which have dimension of specialization, innovation, speed, flexibility, and range improvemnt regarding to optimalization of poverty reduction in Kendari City. The research results showed that the concept of the network which is modeled in poverty reduction is by the hierarchy model and by the actor of TKPKD incorporated in a framework of "Setting Institutional". The network of reducing poverty in Kendari City was not successed caused by the available of conventional network pattern and also the network members not funtion optimally. By using qualitative approaches, the relationship between actors in the network and among stakeholders for the success of poverty alleviation were founded. The concept of poverty alleviation is not more relevant approached by using economic approach but should be approached through a new approach, namely network approach to the prosperity. This approach involves the optimalization of using resources in each organization unit that is collaborated in one rule to find out the prosperity.
\end{abstract}

Keywords: organization network, Reduction of Poverty

\section{Introduction}

Poverty is not only a problem for developing countries, even developed countries also experienced the poverty although not a big as developing countries. The problem feced is the same but the dimension is different. The issue of poverty in developed countries is the smallest part in their community component, but in developing countries the issue becomes more complex caused by the number of poor people nearly achieving half of the total population. Moreover, there are very poor countries have large numbers of poor people exceeds two-thirds of the population (Booth dan Sundrum, 1987).

Based on the identification of the poor people in Indonesia in 2009 done by BPS, the number of poor people in the Kendari City are 15.635 families. Meanwhile, according to Community Empowerment Board of Kendari, number of poor people in the Kendari City are 16.795 households (33.15\%) or 66.549 people $(30.55 \%)$. Kendari Daily Post (July 19, 2012) also showed that the diversity of this data, where the Social Protection Program Data Collection (PPLS) conducted by BPS in 2008 are 19.525 RTS and in 2011 are 19.233 RTS. The same thing was showed by the Jamkesmas data revealed that the submission of Jamkesmas only based on quotas from the Ministry of Health (Kendari Pos Date May 24, 2012). The result of the preliminary observations also indicated that poverty is not only handled by the Agency for Community Empowerment of Kendari City, but also all related parties, such as Social Department and even handled by the Public Works Department through improving slum housing.

Overall the phenomenon showing that there is something wrong in reduicing the poverty in Kendari City, wherein each of organizations data are different, even the implementation of programs are conducted sectoral. Therefore, it will also have an impact on poverty reduction efforts by the organization (institution). This has been confirmed in Article 4 of Regulation No. 11, 2011 which states that the poverty reduction aims to: (a) ensure the protection and fulfillment of basic rights of the poor people, (b) accelerating decline in the number of poor people, (c) increase the participation of citizens communities and businesses, and (d) ensure consistency, integration, synchronization, and synergy in reducting poverty.

This statement showed that the implementation of poverty re duction is not a program that just making a satisfaction in one sector, but trying to solve poverty totally, and the involvement of multiple stakeholders is not a format that was originally done.

Referring to the above, the poverty covering various aspects which is certainly also including a variety of agencies or related stakeholders. The existence of such a situation requires a solution to the poverty that involves all stakeholders associated with poverty, where the decision making model called the integrated decision-maing basis inter-organizational networks (Alwi, 2011). 


\section{Network Of Organization}

Nowadays, there is a new trend which the government is expected to emphasize the network both vertically and horizontally. Vertical network emphasizes how relationships with the higher government structures in order to find out advantage for both sides, while the horizontal network is have direct relation to the public, namely how to serve and work with available communities, NGOs, and private parties so that all of them may be obtaining expected satisfaction.

In the view of experts of network theory, normative approach focusing on culture and socialization processes that embed (Internalization) norms and values into the actor himself. According to the normative approach, which is making people into the unity is the collection of ideas. Network theorists reject this view and stated that people should be focusing to objective bonding patterns that connecting to the members of the community. After explaining what is not as the target of his attention, and network theory explains the main object of attention, namely the objective pattern of bond that connecting to the members of society (individual and collectivity). Wellman said the main object of attention of network theory as follows: One characteristic of network theory is focusing the attention form the micro to the macro structure. It means that , in the network theory, the actor may be individuals (Wellman and Wortley, 1990), but may also in the group or companies (Baker, 1990; Clawson, Neustadtl, and Bearden, 1986; Mizruchi and Koening, 1986) and even the community.

\section{Policy Implementation}

Implementation is often used to describe the stages of implementation of a policy. Inequality unity conceptual definition of the implementation, in addition to a regular phenomenon in the social sciences, is also due to the fact that the so-called implementation activities, is a complex and intricate steps. Some expert opinions regarding public policy, as proposed by Harold Lasswell (1956), the first experts who determined the implementation concept which became famous in the discipline of political science and policy promote one approach called "policy process approach" or approaches in the policy process . Lasswell argued that the implementation is one part of several stages that should be passed from the whole process of public policy formulation, except making policy agenda, formulation of evaluation and legitimation.

Furthermore the opinion of Jeffry L. Presman and Aaron B. Wildavsky, (1975: 447), states the study of implementation emerged since Erwin Hangrove and Aaron Wildasky written a book entitled "Implementation" with subtitles "How Great Expectation in Washington are dashed in oacland; or Why it's amazing that federal program work at all". Research focus on networking in policy implementation. In this study stated that the implementation of the policy is determined by the relationship between the various organizations at the local level. It is also stated that if the implementation of the policy depends on a series of relationships at the local level, the inter institutional or agency cooperation arerequired to make the connection or the network with real world, if not there will be a significant deviation between the policy defined by the implementation or has failed.

\section{Poverty}

Poverty is one of the social problems that are closely related to social policy. The history of the social policy can not be separated from the presence of the problem of poverty in the community. Poverty is a social problem that most known by people. Eventhogh, many people who say that poverty is the root of social problems. Poverty affects other social issues. Various ways have been made to overcome poverty by spending huge funds. In Indonesia, the poverty reduction usually increase every years, with the total funds from Rp. 18 trillion in 2004 up to Rp. 23 trillion in 2005. In 2006, the budget was increased almost two-fold to Rp.42 trillion, and for the year 2007 allocated up to Rp.51 trillion (Voice Reform, 2007). The discussion of poverty always done in a seminar where a few consultants, managers of program and social tasks involved in reducing poverty have instead of wealth abound. Poverty is a tragedy as well as "business" a sparkling humanity.

National Planning Board (BAPPENAS) (2004: 28) give definition to the poverty as a condition in which a person or group of people, men and women, are not able to fulfill their basic rights in order to maintain and develop a dignity life. Furthermore, according to BAPPENAS (2004: 30) indicates that the root of poverty is not only to be sought in the culture of lazy work hard. Overall situation that causes a person not be able to fully carry out productive activities should be taken into account. The factors of poverty is a combination of internal and external factors. The wrong development policies included in the external factors. The corruption which led to a reduction in the budget allocation for development activities for the welfare of the poor people was also included in external factors.

\section{Research Method}

In this study, the assessment is done is to describe the Poverty Reduction Network Implementation with case studies on poverty penanggulangahn Coordination Team kendari City, the method used is a qualitative method. A qualitative approach is used to explain and answer the problems that have been formulated and are already established. Because the study was classified as the type of qualitative research, the method used in this 
research is descriptive qualitative explanatory. In qualitative research data processing and analysis is an indispensable activity. It can be seen on the stages of qualitative data analysis made by Moleong (1997), namely data reduction, data display and conclusion drawing / verification.

Implementation of the Poverty Reduction Network Model

\section{Research Results}

The results of the study will begin by describing the organizational model analysis of poverty reduction, the data will be analyzed from the results obtained documents that researchers, based on the implementation of the programs implemented herarki good for national, regional to the local level, and will be followed by analysis of tissue in poverty reduction.

\section{Theoretical Model}

In simple terms it can be said that the theory of the structure of the network has a powerful models (network relations), while the model of exchange theory has strong relationships between actors (exchange). Social exchange theory model of exchange actors to increase profits will complement the content belongs less network analysis, and network analysis will provide a model of social structure as an independent variable is not fully exchange theory.

Assumed that the opportunity for this exchange is directly related to the network structure. As a result of their position in the network that are members TKPKD, actors will innovate to develop the ability to apply the specialization of each program on education that is affordable, so berimplkasi on achieving organizational goals as well as policy objectives.
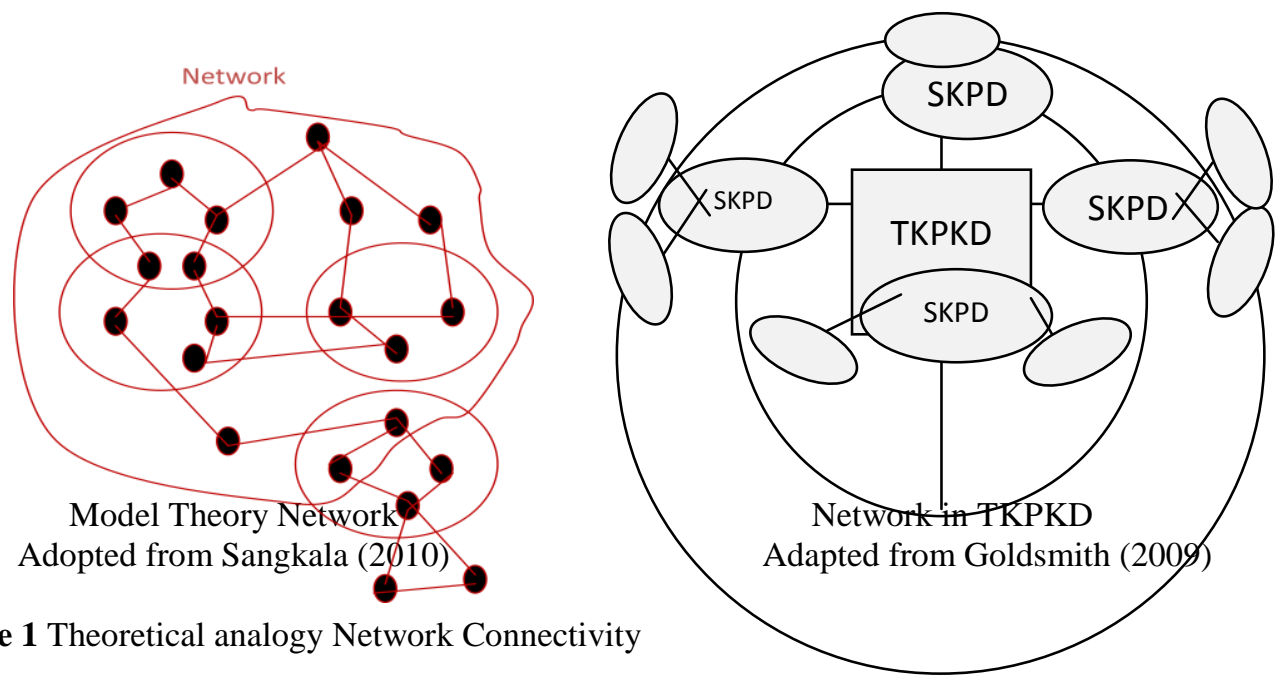

Figure 1 Theoretical analogy Network Connectivity

As is explained above, that in a management requires collaboration, where the management of the affairs of the poverty reduction also developed Collaborative Governance. Roger Sidaway (2005). Collaborative governance in which to develop collaboration and empowerment.

Collaboration in the implementation of poverty reduction policies in Kendari applied in the form of data exchange in Chris Huxham and Siv Vangen (2003:15) emphasizes the exchange of information and the changes in activity and share / contribute resources to achieve mutual benefit and achievement of common goals. This level requires a commitment to a shared vision for the organization's top job. Collaboration is a useful relationship to each other and better between two or more organizations to achieve common goals, involvement in building the structure and shared responsibility, authority and accountability among others to succeed, the sharing of resources and results.

\section{Empirical Model for Poverty Reduction Network}

Empirical model of network implementation of poverty reduction, will be illustrated by explaining repleksi of institutions (institutions) that are functionally and legitimate organization with functional tasks mandated to reduce poverty, and TKPKD beranggotan existing formal institutions (on education). 


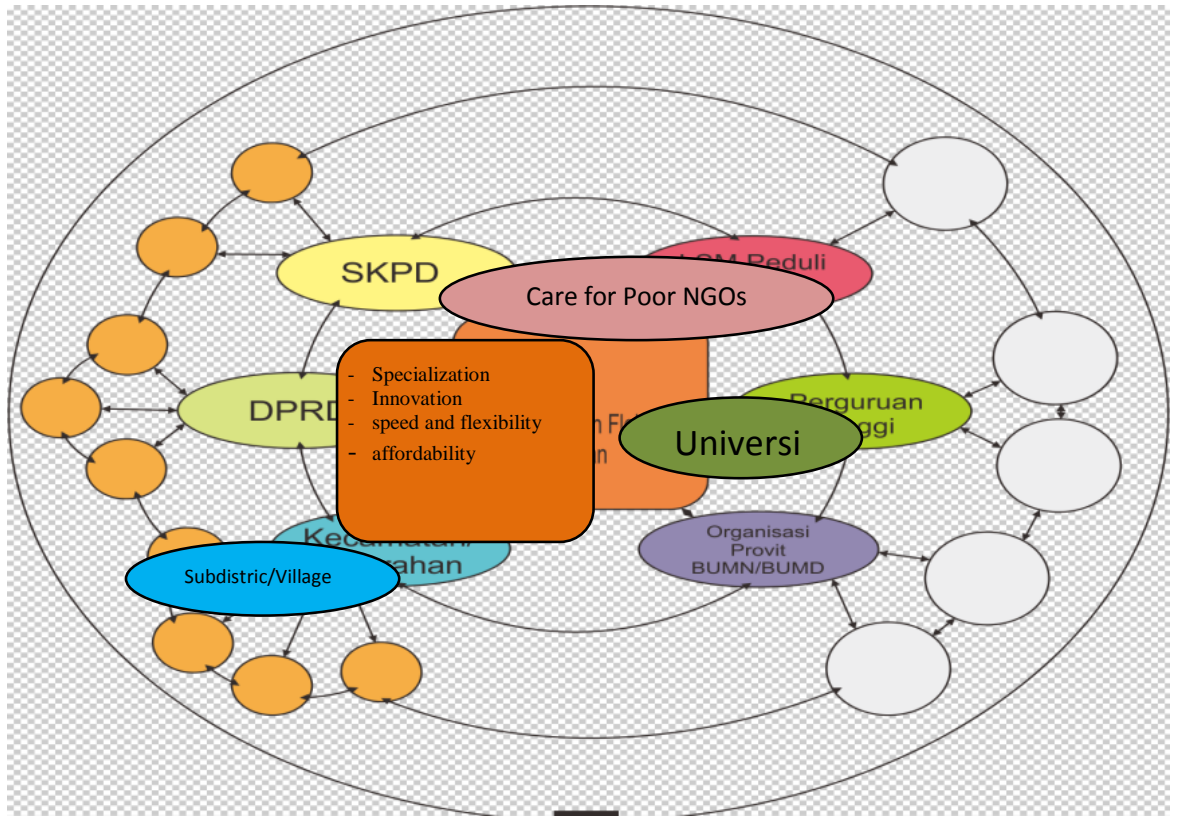

Figure 2 Empirical Model Network in TKPKD Contex

Picture above, shows that the alternative to the effective implementation with the ultimate goal of the research is the specialization, innovation, speed, flexibility, and increase range, (Goldsmith, 2010) and in pelaksanaannnya, developed through a mechanism in the form of organizational communication networks.

Empirical model of network implementation of poverty reduction in Kendari, referring to the synergy and implementation of poverty reduction with TKPKD. The role of institutions that affect the implementation, with a focus on the theory of public institutions, with a focus on how the structure and organization shape the behavior of public actors, especially how variation in the structure affects decision-making, program implementation, including the implementation of poverty alleviation is how the start of national, provincial and local. One fundamental question is Is poverty program is limited to programs that can be classified in a form that is herarki been legislated and are well known and have been there in the instructions for the implementation of poverty reduction? The answer is; poverty alleviation programs are not limited to the activities already terjebarkan centrally and which are well known. Grouping the program itself is basically just to facilitate the identification of each program based on the characteristics of the target base (the beneficiaries) and its purpose, so that it can be seen how the program can support the strategy (acceleration) of poverty reduction has been determined. Beyond the conventional thing earlier, poverty reduction programs may also include other programs throughout the goal is to increase economic activity and prosperity.

The depiction above, in line with the continued question: If there is a local initiative program is identical to the national program or center, can TNP2K mediation efforts to support increased program effectiveness.

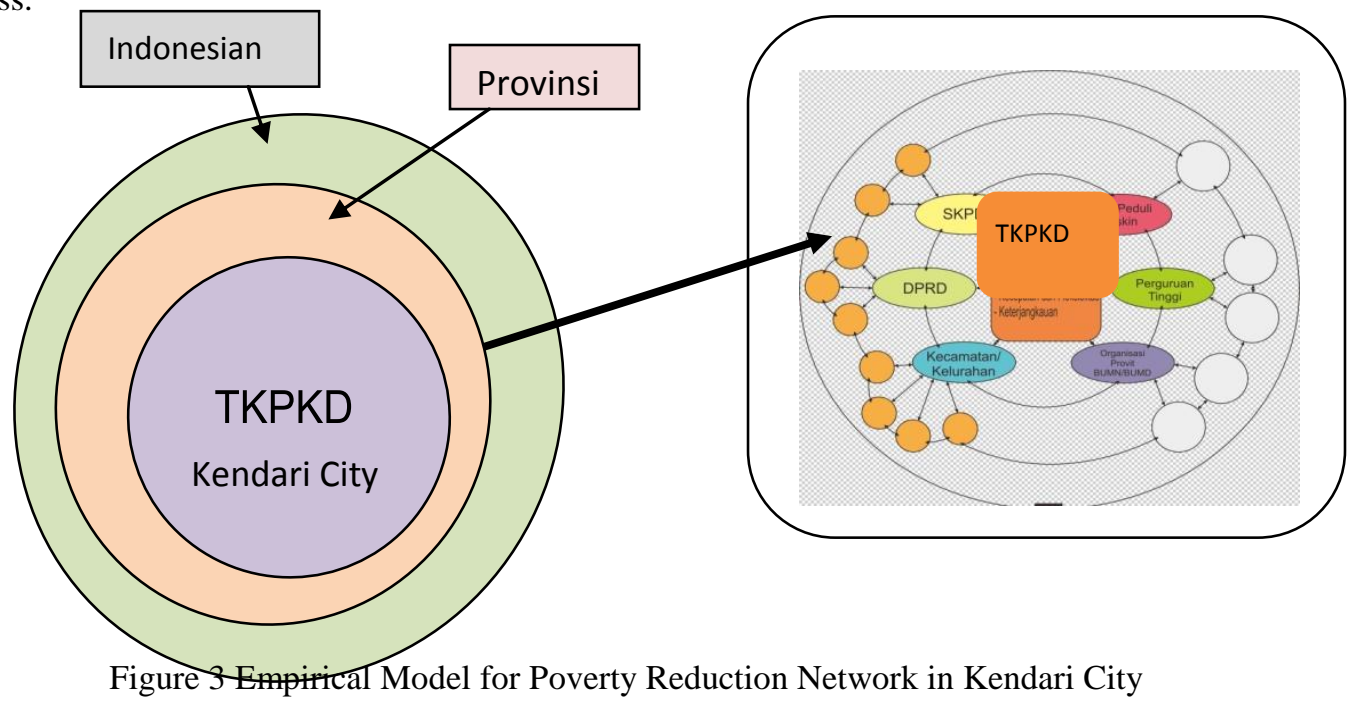


In the context of the program, TNP2K facilitate mediation efforts enhancing the effectiveness of poverty reduction programs, both at the central and regional levels. Since one of the goals is to make the establishment TNP2K synergy through synchronization, harmonization, and integration of poverty reduction programs to scale kendari city, which has been described in the implementation of poverty reduction programs from the central level to the local level of Kendari.

\section{Iternative models of Network Implementation}

Implementation of the policy was impressed the planning underdone because the government saw many additional poor people who caused the economic crisis and financial crisis and other prolonged reaction arising from the various groups which tend to no longer pay attention to the culture and ethics that lead to the onset of unrest and tension in various places as driven and co-opted by other radical groups are not satisfied with the government's policy.

Of the two reasons mentioned above, it appears that poverty is no longer appropriate approached by purely economic approach but needs to be approached through a new approach, namely network approach to prosperity. This approach involves optimizing the pooling of resources in any organization that collaborated on an order concerning the welfare toward economic and non-economic issues and is no longer on the approach and the approach by the study group but mempertautkan people and groups earlier into the same desire, to also consider the proximity between government officials and communities through partnership and dialogue to reach a consensus as well as the transformation process more transparent information and innovation technologist and participation of various parties.

Poverty reduction strategies with the new paradigm is the paradigm of network optimization to prosperity. This paradigm is not only prioritize the purely economic aspects but more important is to grow and develop the insight, knowledge, skills, attitudes and behavior of target families without actors or facilitated both actors, in order to access the resources, capital, markets, and information technologies in the welfare can turn independently. Poverty reduction strategies with this new paradigm, using a network approach to organizational well-being, with this approach, is expected to directly touch the economic base in addition to also pay attention to aspects of key resources and even social and cultural aspects of the poor.

Key to poverty reduction in network optimization approach to the well-being patterned on 3 (three parts), namely: (1) managing access to resources, (2) management of network access to government organizations, and (3) the optimization of the management of non-governmental networks

First, the management of inter-community network, which brings together the management of the components within a framework and a rational connection between the various views and capabilities.

The second is the implementation of a community component in optimizing the organization of government, exemplified by the civil fraternity facilitation program, the existing poverty alleviation programs of the center and the provinces. This pattern can be used in principle approach to group, family, harmony, leadership of the group, partnership, self-help, and learn by doing.

Third, the application components in an organized society groups (NGOs) or other business bina (state / local enterprises) in an optimization of the organization both government and non-government, exemplified by facilitating the implementation of the credit pattern educate and discipline for the poor and other marginal groups so ultimately have the credibility to deal with the Bank normally. Poverty reduction in visualization models with analytical network model can be described as follows:

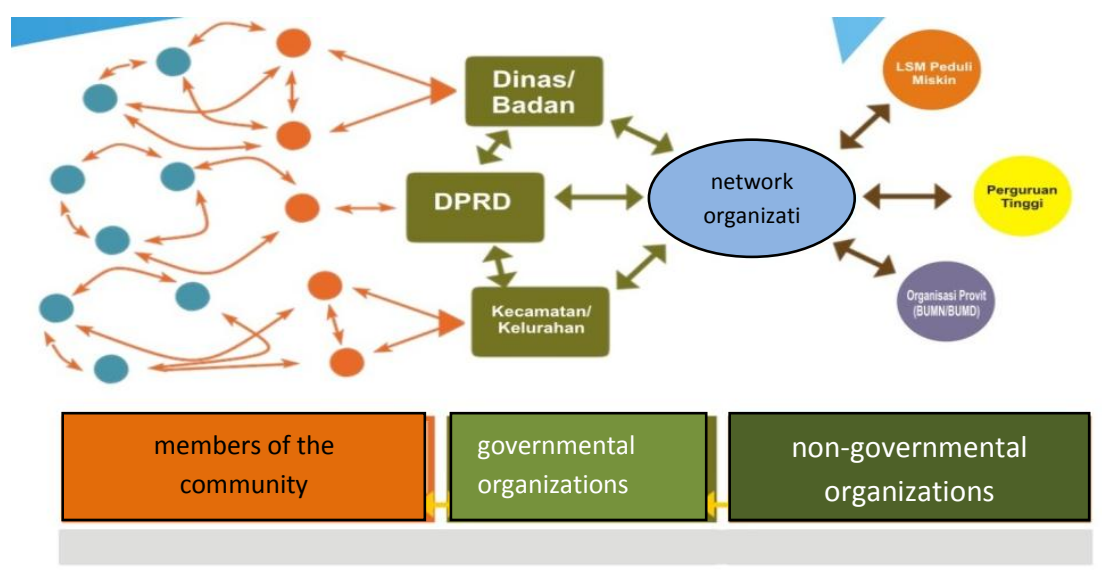

Figure 4 Analogy of Network Model Offered 


\section{Conclusion}

Network model is patterned in poverty reduction with herarki models and actors involved in the network of organizations associated with the implementation of poverty reduction programs in Kendari, a proportion partly involved directly while others not directly involved, partly actors and partly formal role again an actor with a role that informal. Actors in poverty reduction programs in Kendari TKPKD incorporated in a network framework, in which the network is an "Institutional Setting" which is formal and informal, and are assumed to have a different framework both in the implementation and in determining the choice of the similarities in the decisions that will implemented. Actors in the organization's network activity related to the implementation of poverty reduction programs with a focus on; beneficial synergy to each other and preferably between two or more organizations to achieve common goals, activity actors in the policy implementation process include: Personal relationships between actors in the form of exchange of ideas, exchange of information, the relationship between actors regarding herarki position, and coordination, goal related to the actor's participation in the program, strategies to maximize the effect and the actor in which the organization's objectives and rules of the game are actors who adapted to the role of other actors such as openness, legality, balance between roles and so on.

Role of Institutions (institutions) in the process of policy implementation, with a focus on how the structure and organization shape the behavior of public actors, especially how variation in the structure affects decision-making and implementation of programs, where the result is: (a) The number and stability in membership network, (b) absorption of the organization's network of different actors organization's vision and mission, (c) The division of labor transfer and organizational actors, (d) Distribution of roles and responsibilities between actors and organizations. Network model is characterized by a pattern of innovation will implmentasi local level.

[1] Alwi..dan La Tamba. 2011. Wicked Problem dan Pendekatan jaringan Dalam pengentasan Kemskinan di Indonesdai. Makalah yang disajikan dalam Seminar Nasional "Penguatan Administrasi Publik / Negara Untuk Kesejahteraan Rakyat ; Tinjauan kebijakan dan Manajemen Publik, Makassar 7 sampai 8 Juli 2011.

[2] Aquaaah Moses, 2006, The Impact Of Managerial Networking Realitionship on Oragnizational Performance in Sub Saharan Africa ; Evidence From Ghana. Organization Management Journal Vol. 3, No. Eastern Academy of Management University of North Carolina at Greensboro

[3] Barnard, Chester I. Function Of The Executif. Cambridge. Mass. Harvarad Univ Press, 1938

[4] CESS, 2003, Program Antikemiskinan di Indonesia, Pemetaan Informasi dan Kegiatan. Center for Economics and Social Studies, Jakarta:

[5] Coco Malcolm, dkk. 2012. Organizational Social Networking Policy Restriction, International Jiurnal Of Business and Public Administration, Volume 9 Number 1, Gundar Kaupins Boise State University, Winter 2012.

[6] Faturochman, et.al. (2007), Membangun Gerakan Penanggulangan Kemiskinan Melalui Pemberdayaan Masyarakat, Yogyakarta, Pusat Studi Kependudukan dan Kebijakan, Universitas Gadjah Mada

[7] Goldsmith, Stephen and Eggers, William. 2004. Governing By Network. The Brooking Institutions. Massachusetts Avenue, New York. Washington

[8] Goldsmith, Stephen and Donald F.Kettel (editor), 2009, Unlocking The Power Of Network: Keys To the Hight Performance Government, ash institute for Democratic governance and innovation John F. Kennedy School of Government Harvard University, Brookings institution press Washington, D.C.

[9] Moleong, Lexy J, 2010. Metodologi Penelitian Kualitatif. Edisi Revisi. Cetakan Kedua Puluh Enam. Remaja Rosdakarya. Bandung.

[10] Sangkala 2010. Perubahan Paradigma Administrasi Negara dan Implikasinya Terhadap Karakter dan Desain Birokrasi Dalam Pelayanan Publik. (Diucapkan pada Upacara Penerimaan Jabatan Guru Besar Dalam Bidang Kebijakan Publik). Universitas Hasanuddin. Makassar.

[11] Sangkala, 2011, Perubahan Paradigma Administrasi Negara Dan Implikasinya Terhadap Karakter dan Peran Birokrasi Dalam Pelayanan Publik (Jurnal Ilmu Administrasi Negara dan Manajemen Publik). IAPA. Bandung.

Other Documents

[12] UU No 11 Tahun 2009 tentang Kesejahteraan Sosial.

[13] Peraturan Presiden Nomor 15 Tahun 2010. Tentang Tim Koordinasi Penanggulangan Kemiskinan

[14] Peraturan Daerah Nomor 11 Tahun 2011 tentang Penanggulangan Kemiskinan Kota Kendari.

[15] TKPK (2009) Panduan Program Nasional Pemberdayaan Masyarakat (PNPM). Versi Desember 2009. Tim Koordinasi Penanggulangan Kemiskinan. 